\title{
Reverse osmosis as one-step wastewater treatment: a case study on groundwater pollution
}

\author{
Wajid Ali, Waheed Ur Rehman, Mohammad Younas", Muhammad Imran Ahmad, Saeed Gul \\ University of Engineering and Technology, Department of Chemical Engineering, Peshawar-Pakistan, P.O.Box. 814, \\ University Campus Peshawar 25120 \\ "Corresponding author: e-mail: m.younas@uetpeshawar.edu.pk,u4unas@gmail.com
}

\begin{abstract}
The present case study is focused on performance evaluation of a Reverse Osmosis (RO) membrane based pilot plant to treat the ground/surface drinking water sources polluted by flood, rivers and/or canals. The RO plant was designed, fabricated and then operated with polluted water. Two feed water samples having a TDS of 2.000 $\mathrm{mg} \cdot \mathrm{L}^{-1}$ and $10.000 \mathrm{mg} \cdot \mathrm{L}^{-1}$ respectively, were taken and analyzed for physical, chemical and microbiological contaminants. The RO plant was run once through over a span of $100 \mathrm{hrs}$ at an operating pressure of 15 bar. TDS rejections were found to be more than $94 \%$ while permeate flux was measured to be $25.82 \mathrm{~L} \cdot \mathrm{m}^{-2} \cdot \mathrm{hr}^{-1}$ to $40.55 \mathrm{~L} \cdot \mathrm{m}^{-2} \cdot \mathrm{hr}^{-1}$. Results show that RO plant has a potential to remove physical, chemical and microbiological contaminants like Total Coliform and E. Coli in one step.
\end{abstract}

Keywords: Reverse Osmosis (RO), membrane separation, Total Dissolved Solids (TDS), Total Coliform, E. Coli.

\section{INTRODUCTION}

Due to rapid growth in world's population and scarcity in natural resources, the significance of clean drinking water is increasing, both in terms of quantity and quality. As the drinking water has to pass through different channels, it mostly gets contaminated. The contaminated water sources have both direct and indirect effects on human health such as diarrhea, cholera, typhoid, and fever, ${ }^{1,2}$.

The traditional treatment of pathogenic microorganisms has been analyzed in different studies on tertiary/chemical treatments ${ }^{3-7}$. However, the conventional wastewater treatment methods are not able to completely remove the suspended particles and/or smaller inorganic salts. In contrast, membrane processes have proved to be an efficient technique in removing almost all kinds of contaminants and producing the finest quality of drinking water. The most common membrane processes are the microfiltration (MF), ultrafiltration (UF), nanofiltration (NF) and reverse osmosis (RO). Membranes can produce a better quality water but at the expense of cost. Operating cost increases with increasing removal of ions and particles by the membrane ${ }^{8-11}$.

Being one of the finest filtration techniques, $\mathrm{RO}$ is now widely used for effective and economical treatment of brackish as well as seawater. Design considerations of RO system depend on total dissolved solids, organic contaminants, suspended solids and desired quality of produced water. The RO membrane acts as a barrier to all dissolved salts and inorganic molecules, as well as organic micro molecules. Water molecules, on the other hand, pass freely through the membrane, thus creating a purified product stream. The water produced (Permeate) satisfies most of the water quality standard parameters ${ }^{8,10,12}$.

RO membranes have the potential to remove the organic, inorganic and biological contaminants from saline and ground water ${ }^{13}$. But membrane fouling in RO membrane, limit the use of this process for water treatment. The main fouling mechanisms in RO membranes include colloidal fouling (particulate deposition), biofouling (microbial adhesion and growth), organic fouling (adsorption of organic compounds), and inorganic fouling (scaling) ${ }^{14}$. To address this problem, a pretreatment step is always preferred before treating the effluent with RO. Beside this, fouling can be eliminated by choosing benign design and operating conditions. However, at commercial competitive fluxes, fouling is ubiquitous. Though, routine cleaning of membrane at the end of each day (experiment) with chemicals reduces the part of adsorption resistance, irreversible fouling of membrane can not be completely eleminated ${ }^{15}$. Winfield found that role of dissolved solids is greatly important in RO membrane fouling as compared to the effects of suspended solids ${ }^{16,17}$. RO membranes can easily be fouled due to microbial growth ${ }^{17,18}$.

Likewise, concentration polarization also reduces the plant efficiency ${ }^{\mathbf{1}}$. Concentration polarization is the accumulation or depletion of solutes near an interface. As a result of water crossing the membrane, the solute is concentrated on the feed side of the membrane surface and diluted on the permeate side. As, an asymmetric membrane is used in $\mathrm{RO}$ which comprises of a thin dense layer on top of a porous supported layer, concentration polarization occurs externally on the dense layer and internally on the supported layer side ${ }^{20,21}$.

Hastutu and Wardiha studied the treatment of brackish water in Indonesia's coastal area with UF and RO. They found the coupled UF and RO process to be a better choice for obtaining drinkable water from brackish coastal water ${ }^{22}$. Afonso et al. studied the techno-economical aspects of brackish ground water treatment by MF and RO. They found that potable water could be produced by $\mathrm{RO} / \mathrm{NF}$ at reasonable price ${ }^{23}$. Nataraj et al. found hybrid $\mathrm{RO} / \mathrm{NF}$ as a useful technique to treat wastewater like one from distillery that is highly polluted with physical and biological pollutant load ${ }^{24}$.

Some of the researchers studied one step membrane based wastewater treatment unit and found satisfactory results. Bruggen et al. carried out experiments on nanofiltration and found it to be a suitable technique for treatment of ground and surface water contaminated with micro pollutants, viruses and bacteria ${ }^{10}$. In another study 
Bruggen et al. removed pesticides and hardness in one-step with $\mathrm{NF}^{\mathbf{1 1}}$. Yavuz et al. used spiral wound Film Tec ${ }^{\mathrm{TM}}$ SW30-2540 RO membrane to treat the geothermal water for boron rejection. A rejection of $84 \%$ was noted at 20 bar $^{25}$. Jawad et al. considered RO membranes suitable for urban wastewater treatment at Kuwait ${ }^{26}$. Additional research is needed to verify and test the theory to remove all the physical, chemical and biological pollutants through RO in one step. Such research will be helpful in providing drinkable water in flood affected remote areas of undeveloped or underdeveloped regions of the world.

Contaminated drinking water is one of the major health hazard issues in Pakistan. In order to facilitate the community with quality drinking water, a domestic level RO plant may solve the problem in a better way. The present study is aimed to evaluate the performance of a Reverse Osmosis (RO) pilot plant to treat the ground/ surface drinking water sources polluted by flood, rivers or canals. The RO Plant was fabricated and then tested to remove the suspended solids, total dissolved solids, turbidity and pathogenic microorganisms from source water. The RO plant was operated continuously for 20 days with 5 hrs of plant operation per day.

\section{MATERIAL AND METHODS}

\section{Raw water characteristics}

A model solution of raw feed water was prepared according to the pollutant strength equivalent to the mean pollutant strength of water taken from the surface/ground of rural areas inundated by rivers, canals or flood. The main quality parameters of raw water are shown in Table 1.

\section{Membrane and experimental setup}

A pilot scale RO unit was fabricated with vertically installed membrane module. Schematics of the unit are shown in Figure 1. Dow Filmtec ${ }^{\mathrm{TM}}$ BW30-4040 RO membrane was used in the plant. Specifications of the membrane are given in Table 2. Samples from the wastewater to be treated were analyzed for physical, chemical and bacteriological parameters. In the experimental setup, wastewater from feed tank was first passed through a $5 \mu \mathrm{m}$ filter cartridge. It was then pumped to the RO

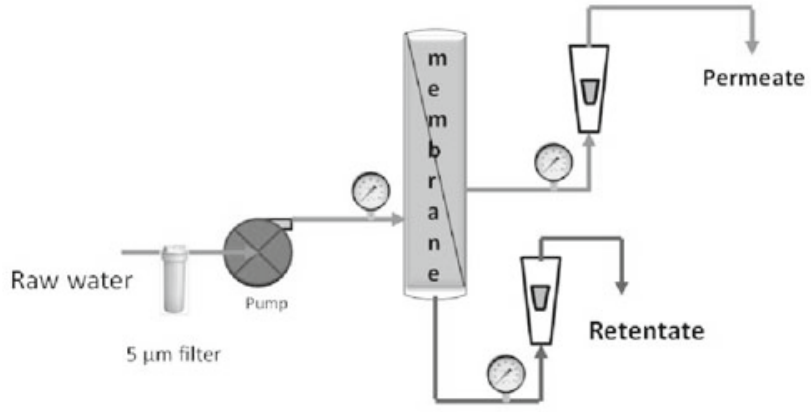

Figure 1. Reverse Osmosis (RO) based pilot scale unit for wastewater treatment

Table 2. Dow FilmtecTM BW30-4040 Industrial Reverse Osmosis Membrane Specifications (provided by manufacturer)

\begin{tabular}{|l|c|}
\hline Dimensions & $3.9^{\prime \prime} \mathrm{W} \times 40^{\prime \prime} \mathrm{L}$ \\
\hline $\begin{array}{l}\text { Maximum Operating } \\
\text { Temperature }\end{array}$ & $113^{\circ} \mathrm{F}\left(45^{\circ} \mathrm{C}\right)$ \\
\hline Active surface area & $78(7.2) \mathrm{ft}^{2}\left(\mathrm{~m}^{2}\right)$ \\
\hline Permeate Flow Rate & $2400 \mathrm{gpd}\left(3.2 \mathrm{~m}^{3} / \mathrm{d}\right)$ \\
\hline Maximum Operating Pressure & $600 \mathrm{psi}(41 \mathrm{bar})$ \\
\hline Maximum Feed Flow Rate & $16 \mathrm{gpm}\left(3.6 \mathrm{~m}^{3} / \mathrm{h}\right)$ \\
\hline Stabilized Salt Rejection & $99.5 \%$ \\
\hline $\begin{array}{l}\text { pH Range, Continuous } \\
\text { Operation }\end{array}$ & $2-11$ \\
\hline $\begin{array}{l}\mathrm{pH} \text { Range, Short Term } \\
\text { Cleaning }\end{array}$ & $1-12$ \\
\hline $\begin{array}{l}\text { Membrane Type } \\
\text { Polyamide Thin-Film } \\
\text { Composite }\end{array}$ \\
\hline
\end{tabular}

membrane with a pressure of 10-20 bars, which split the feed water into permeate and retentate streams. Gradual increase in pressure at the membrane inlet caused an increase in permeate flux with an improved water quality. Permeate and rententate streams were stored in separate storage tanks. A part of retentate stream was recycled back to the feed tank in batch process. The permeate flow rate was $22-27 \%$ of the feed flow rate. $73-78 \%$ of the feed water was recycled back to the feed tank during experimentation. The feed flow rate was kept

Table 1. Raw water (feed) quality parameter

\begin{tabular}{|l|c|c|}
\hline Quality parameters & WHO Standards [25] & Raw water quality [Avg] \\
\hline Colour & $\leqslant 15 \mathrm{TCU}$ & Bad \\
\hline Taste & Acceptable & $650-1100$ \\
\hline $\mathrm{TH}$ & $<500 \mathrm{mg} / \mathrm{L}$ & $2000-10000$ \\
\hline TDS & $<1000$ & $7-23$ \\
\hline Turbidity & $<5 \mathrm{NTU}$ & $6.5-8$ \\
\hline $\mathrm{PH}$ & $6.5-8.5$ & $1.6-5.5$ \\
\hline $\mathrm{NO}_{2}$ & $\leqslant 0.5 \mathrm{mg} / \mathrm{L}$ & $40-60$ \\
\hline $\mathrm{NO}_{3}$ & $\leqslant 50 \mathrm{mg} / \mathrm{L}$ & $500-1000$ \\
\hline Chlorides as Cl & $250 \mathrm{mg} / \mathrm{L}$ & $1000-3500$ \\
\hline Total Plate Count (TPC) & $100 \mathrm{CFU} / \mathrm{ml}$ & $356->1000$ \\
\hline Total Coliform & $0 / 100 \mathrm{ml}$ & + \\
\hline Fecal Coliform & $0 / 100 \mathrm{ml}$ & + \\
\hline E. Coli & $0 / 100 \mathrm{ml}$ & + \\
\hline
\end{tabular}


constant at $12.60 \mathrm{~L} / \mathrm{hr}$ while permeate flux varied from 20-30 L $\cdot \mathrm{m}^{-2} \cdot \mathrm{h}^{-1}$ due to an increase in concentration of feed water by recycling retentate streams. Continuous process was employed in most of the experimentation and there was no recycle stream. The feed water quality was maintained constant throughout the process. Gate valves were installed on permeate and retentate streams to control flow and pressure thus managing water quality. Pressure gauges were installed at pump's discharge, membrane outlet, and permeate and retentate lines to monitor the pressure at each point.

\section{Methodology}

The Plant was operated continuously in a total recycle mode. Permeate and retentate streams were recycled back to the feed tank to keep the feed concentration constant. The plant was operated for twenty days with five hours a day and having ten minutes break after half time period. Quality parameters were measured at the start and end of each day (experiment). These included tests like TDS, pH, Nitrate, Nitrite and microbiological analysis of water including E. Coli, Total Plate Counts and Total Coliform.

Turbidity, TDS and $\mathrm{pH}$ of the water samples were measured with digital Turbidity meter and $\mathrm{pH} / \mathrm{TDS}$ meter, respectively. Nitrate and Nitrite were measured with Hanna Photometer. Microbiological analysis were carried out by using Lauryl Sulfate Agar as a selective method for measuring fecal and total coliform in water. This media enhances the bacterial growth while inhibits the growth of other micro-organisms. A known volume $(60 \mathrm{ml})$ of water was passed through microporous membrane filter and the filter was then placed on absorbent pads (in petri dishes) containing culture media (Membrane Lauryl Sulfate Agar). The petri dishes were then placed in an incubator at a temperature of $37^{\circ} \mathrm{C}$ and observed after 24-48 hours. The fecal coliform, E. coli and total coliform unit was monitored for each sample analyzed.

After each experiment, routine cleaning and maintenance procedure was performed. The RO unit was cleaned with $0.1 \% \mathrm{NaOH}$ and $0.2 \% \mathrm{HCl}$ solutions to remove organic and inorganic contaminants deposited on membrane surface and pipes. The unit was then rinsed with distilled water at a pressure of 5 bar and maximum feed flow rate of $12.60 \mathrm{~L} / \mathrm{min}$. The maintenance period was 35 to 40 minutes.

During each experimental run, the feed flow rate was kept constant at $756 \mathrm{~L} \cdot \mathrm{hr}^{-1}$ and trans-membrane pressure was maintained at 15 bar. The temperature of initial feed was $24-26^{\circ} \mathrm{C}$. Each single experiment was run continously for 5 hours a day. Same experimental procedure was repeated for two different model raw water solutions having a TDS of $2.000 \mathrm{mg} \cdot \mathrm{L}^{-1}$ and $10.000 \mathrm{mg} \cdot \mathrm{L}^{-1}$ respectively.

After wastewater treatment, the post-water quality analysis were carried out and compared with pre-treatment results. Plant efficiency was then calculated from salt rejection, permeate flux and water quality parameters. For the evaluation of water treatment efficiency, raw water and permeate samples were collected periodically. Water quality parameters including $\mathrm{pH}$, turbidity, total dissolved solids, nitrate and nitrite, total coliforms and Escherichia Coli were measured. Salt rejection (R) was measured by $\mathrm{R}=\left(1-\mathrm{C}_{\mathrm{P}} / \mathrm{C}_{\mathrm{F}}\right) * 100$ where $\mathrm{C}_{\mathrm{P}}$ is the salt concentration in the permeate solution, and $\mathrm{C}_{\mathrm{F}}$ is the salt concentration in the feed solution.

\section{RESULTS AND DISCUSSION}

Effect of TDS rejection and permeate recovery as continuous function of time

Most of the quality characteristics of drinking water are described by Total Dissolved Solids (TDS). Permeate water was tested for TDS as a function of operation time. Samples were taken from permeate stream after every 15 minutes. Thus 4 samples in one hour and 20 samples in a single day were tested. Likewise, the next day, wastewater treatment was restarted.

In Figure 2, percent rejection in TDS against operation time is plotted for an initial wastewater of TDS $2.000 \mathrm{mg} \cdot \mathrm{L}^{-1}$ and $10.000 \mathrm{mg} \cdot \mathrm{L}^{-1}$, respectively. Plot shows a decrease in $\%$ rejection of TDS as a function of time. The initial TDS rejection is found to be $98.6 \%$ and $94.1 \%$ for the feed water of TDS $2.000 \mathrm{mg} \cdot \mathrm{L}^{-1}$ and $10.000 \mathrm{mg} . \mathrm{L}^{-1}$, respectively. A decrease in percent rejection was observed with the passage of operating time. However, routine maintenance at the end of the day improved TDS rejetion. After a week of operation, plant performance was found to be decreased. Moreover, TDS rejection dropped rapidly if the plant operated consecutively over 100 hours of continuous operation, although routine maintainane cleaned the membranes to some extent. Such kind of behavior was shown irrespective of feed water pollutants strength. Neverthless, less effect on TDS rejection was observed for low feed strength as shown in Figure 2, for an initial feed TDS of $2.000 \mathrm{mg} \cdot \mathrm{L}^{-1}$. For feed water of initial TDS 2.000 $\mathrm{mg} \cdot \mathrm{L}^{-1}$, decrease in TDS rejection was noticed to be $2.7 \%$ at the end of $1^{\text {st }}$ day and $12.5 \%$ at the end of $20^{\text {th }}$ day of operation. TDS values in permeate water increased from $36 \mathrm{mg} \cdot \mathrm{L}^{-1}$ on $1^{\text {st }}$ day to $343 \mathrm{mg} \cdot \mathrm{L}^{-1}$ on $20^{\text {th }}$ day of operation. Similarly, for feed water of initial TDS $10,000 \mathrm{mg} \cdot \mathrm{L}^{-1}$, decrease in TDS rejection was noticed to be $6.8 \%$ at the end of $1^{\text {st }}$ day and $24.5 \%$ at the end of $20^{\text {th }}$ day of operation. The development of biofilm layer and treating of highly concentrated wastewater increased concentration polarization which resulted in low salt rejection. The addition of low dose chlorine in CIP process and treating for a longer period of time

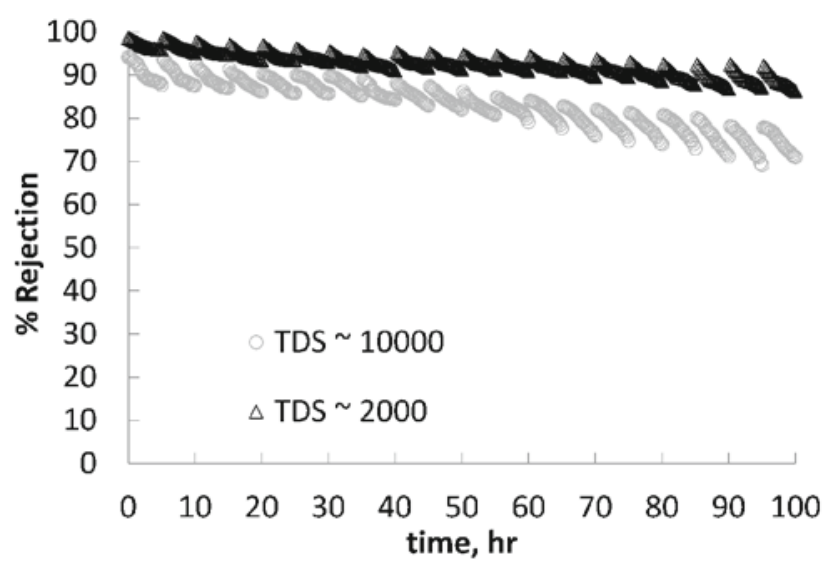

Figure 2. TDS rejection as continuous function of time, $5 \mathrm{hrs} \cdot \mathrm{day}^{-1}$ 
(50-60 minutes) with $\mathrm{NaOH}$ and $\mathrm{HCl}$ solution improved the performance of the RO unit.

Similarly, when the feed of initial TDS $10.000 \mathrm{mg} \cdot \mathrm{L}^{-1}$ was treated, the permeate flux droped from 36.5 to $33.0 \mathrm{~L} \cdot \mathrm{m}^{-2} \cdot \mathrm{hr}^{-1}$ on the first day and 28.3 to 25.7 $\mathrm{L} \cdot \mathrm{m}^{-2} \cdot \mathrm{hr}^{-1}$ on the $20^{\text {th }}$ day of operation. Likewise, as shown in Figure 3, the permeate recovery was noted to be $33.6-35.2 \%$ on the first day and $25.7-28.2 \%$ on the $20^{\text {th }}$ day of operation. It can be observed from Figure 2 and 3 that when feed water TDS increases, a sharp decline in permeate flux and recovery occurs. For example, permeate flux decline and rejection was $6.8 \%$ on the first day, while $8.7 \%$ on the $20^{\text {th }}$ day of operation. Similar behavior was observed for feed with initial TDS of $2000 \mathrm{mg} \cdot \mathrm{L}^{-1}$ as shown in Figures 2 and 3.

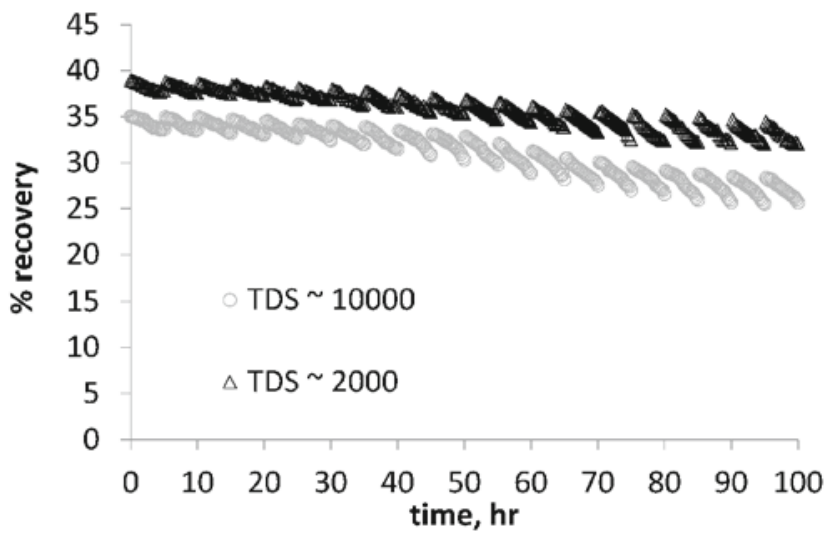

Figure 3. Permeate recovery as continuous function of time, $5 \mathrm{hrs} \cdot$ day $^{-1}$

It was found that permeate flux and recovery depends upon the hydrodynamic conditions like pressure loss, pump power loss, leakages and membrane fouling ${ }^{28}$. Several researchers have explained the effect of operating conditions (feed water quality, pressure and temperature) on performance parameters (permeate flux and recovery). Hastuti and Wardiha operated the brackish coastal water RO treatment plant at lower applied pressures e.g. 5 and 8 bars and noticed the TDS and turbidity removal to be greater than $96 \%$. Permeate flux was measured to be $52-56 \mathrm{~L} \cdot \mathrm{m}^{-2} \cdot \mathrm{hr}^{-1}$ and $28-40 \mathrm{~L} \cdot \mathrm{m}^{-2} \cdot \mathrm{hr}^{-1}$ for applied pressure of 8 and 5 bar, respectively ${ }^{22}$. Similarly, Afonso et al. operated the brackish ground water treatment plant with Film Tec ${ }^{\mathrm{TM}}$ RO membrane (SW30-2521) at a pressure of $20-30$ bars and temperature of $40^{\circ} \mathrm{C}$. They obtained water recovery ratio upto $77.5 \%$ for brackish (feed) water having a TDS range of 948 to $2.288 \mathrm{mg} \cdot \mathrm{L}^{-1} 15$. The feed water quality used by Afonso et al. has almost the same TDS concentration as the one used in present experimental work.

Turan et al. studied dairy wastewater treatment with $\mathrm{RO}$ and found that permeate flux is dependent on transmembrane pressure, feed flow rate and feed pollution load. They observed permeate flux of $25 \mathrm{~L} \cdot \mathrm{m}^{-2} \cdot \mathrm{hr}^{-1}$ for a feed flow rate of $550 \mathrm{~L} \cdot \mathrm{hr}^{-1}$, COD of $10.000 \mathrm{mg} \cdot \mathrm{L}^{-1}$ and applied pressure of 14 bar. A decline of $19 \%$ was observed in permeate flux when feed COD increased from 5.000 to $10.000 \mathrm{mg} \cdot \mathrm{L}^{-128}$. All these studies support our experimental results and give a similar relation of the effect of operating parameters on performance parameters of the RO plant.
Removal of microbial pollutants in continuous wastewater treatment

Microbial analysis of treated water was carried out by calculating Total Plate Counts (TPC), Total Coliform (TC) and E. Coli. Lauryl sulfate Agar was used as a feed for measuring Total Coliform and E. Coli. These analysis depict a clear picture of most hazardous bacteria present in wastewater. These analysis were performed at the start and end of the experiment, each day. As discussed in previous paragraphs, each experiment on a single day lasted for 5 hours of continous operation followed by routine maintenance at the end of the experiment. It can be observed from Figure 4 that TPC counts were in the safe range throughout. However, in a very few samples, it was found that TPC counts were greater than the allowable limits for drinking water. The excess level of TPC counts were noticed in the samples taken at the end of the day. Interestingly, the samples taken at the start of the day showed that TPC counts were within the allowable limits for drinking water.

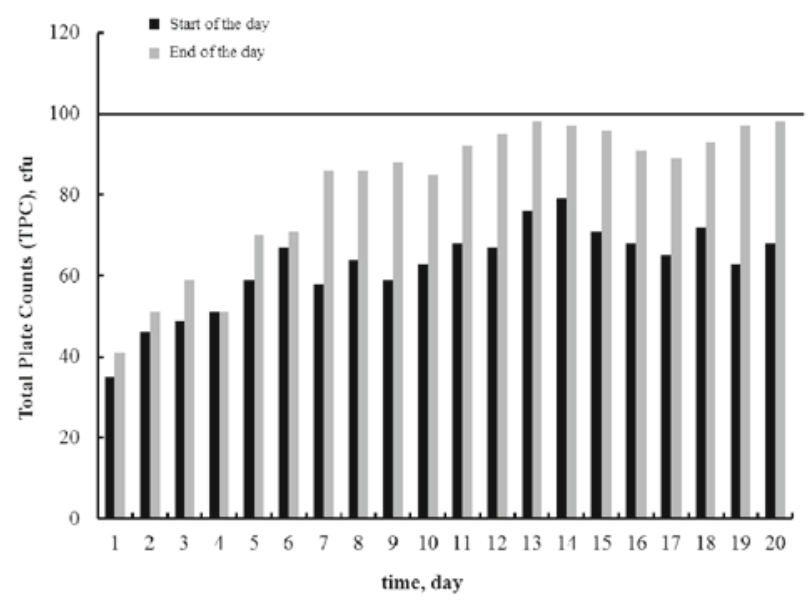

Figure 4. Total Plate Counts (TPC) analysis in continuous wastewater treatment; $5 \mathrm{hrs} \cdot \mathrm{day}^{-1}$

On the other hand, as indicated in Figures 5 and 6, TC and E. Coli analysis do not show satisfactory results. " 0 " indicates the absence and " 1 " indicates the presence of TC and E. Coli. TC and E. Coli were found to be absent in the samples analyzed at the start and end of each day except a few samples. The primary reasons of

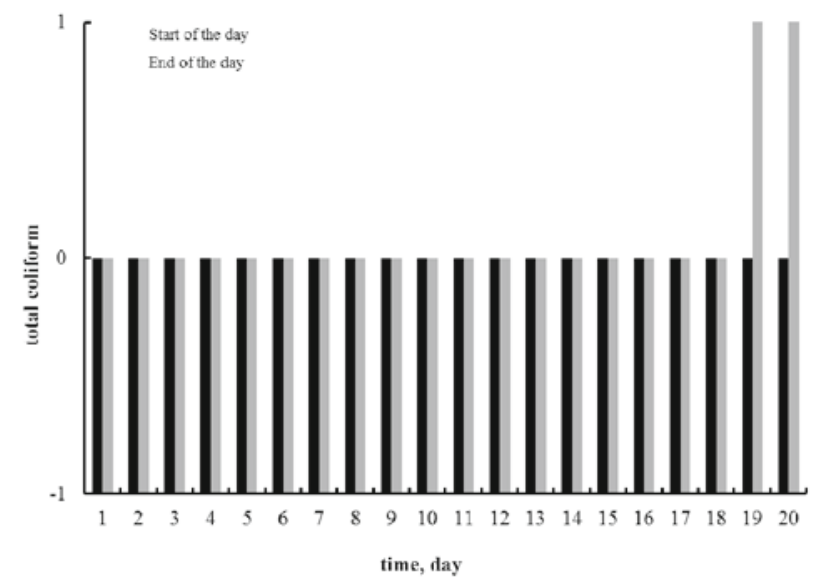

Figure 5. Total Coliform (TC) analysis in continuous wastewater treatment; $5 \mathrm{hrs} \cdot$ day $^{-1}, 0$ : not detected, 1 : detected 


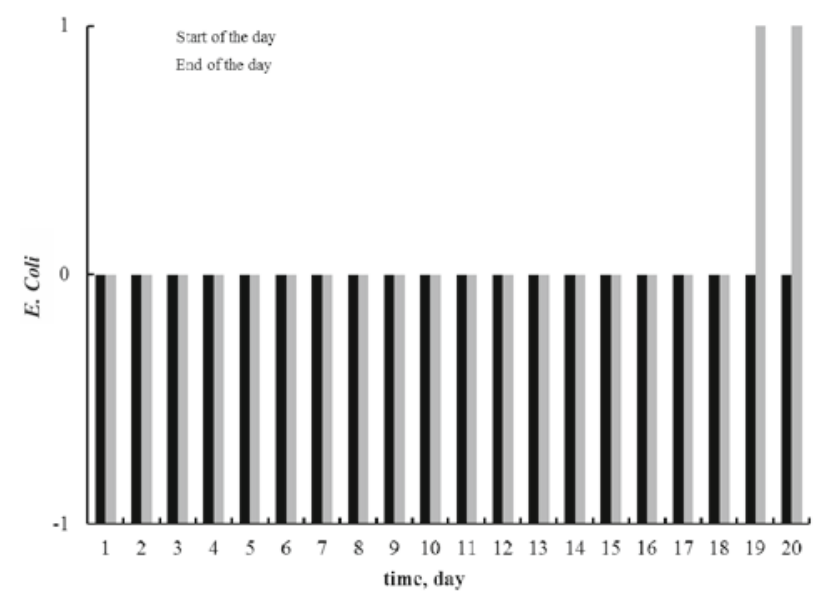

Figure 6. E. Coli analysis in continuous wastewater treatment: $5 \mathrm{hrs} \cdot$ day $^{-1}, 0$ : not detected, 1: detected

membrane fouling are insuffient routine cleaning of the membrane, O-ring leakage, glue line damage or improper handling of the plant or membrane. It was observed that $\mathrm{MF}$ and $\mathrm{RO}$ can not gaurantee the complete removal of microbial contaminants. The presence of these contaminants in permeate water can be attributed to the degradation of membrane surface and inferior packing of module/elements. After each experment, CIP process (treating membrane with $0.1 \% \mathrm{NaOH}$ and $0.2 \% \mathrm{HCl}$ solution) was adopted to remove organic and inorganic deposits on the membrane surface. Improper cleaning process (like insufficient cleaning time or $\mathrm{HCl}$ and $\mathrm{NaOH}$ concentration) leads to an increase in TPC on membrane surface, as well as TPC in permeate water.

Wintgens has broadely reviewed the role of membrane technology in municipal wastewater reclamation and use. It is reported that UF or MF are the indespensible pretreatment steps before NF or RO to retain the microbial contaminants?.

\section{Effect of applied feed pressure on permeate flux and recovery}

The efficieny of RO membrane unit was also measured by calculating the mean permeate flux and mean recovery at different operating feed pressures. Permeate flux and percent recovery at various feed pressures, were measured for distilled water and wastewater (model raw water), at the start and end of each day. It can be noticed in Figures 7 and 8 that permeate flux and percent recovery increased with increase in applied pressure. However, a marginal decrease in flux and recovery was observed for wastewater despite the fact that the membrane was cleaned properly at the end of each day in 20 days experimental run.

Percent rejection of the pollutants like Nitrite as $\mathrm{NO}_{2}$, TDS and $\mathrm{TH}$ as $\mathrm{CaCO}_{3}$ were also measured as a function of applied feed pressure. As shown in Figure 9, rejection of these pollutants increased with the increase in pressure. There was a nominal effect on TDS and TH above the applied pressure of 20 bar. Rejection of Nitrites as $\mathrm{NO}_{2}$ can further be enhanced if applied pressure is increased above 25 bar. Rejection of $\mathrm{TH}$ as $\mathrm{CaCO}_{3}$ was found to be $97 \%$ and $98 \%$ at applied pressures of 20 and 25 bar, respectively. For an applied pressure of 25 bar, TDS and Nitrites as $\mathrm{NO}_{2}$ were found to be $75 \%$

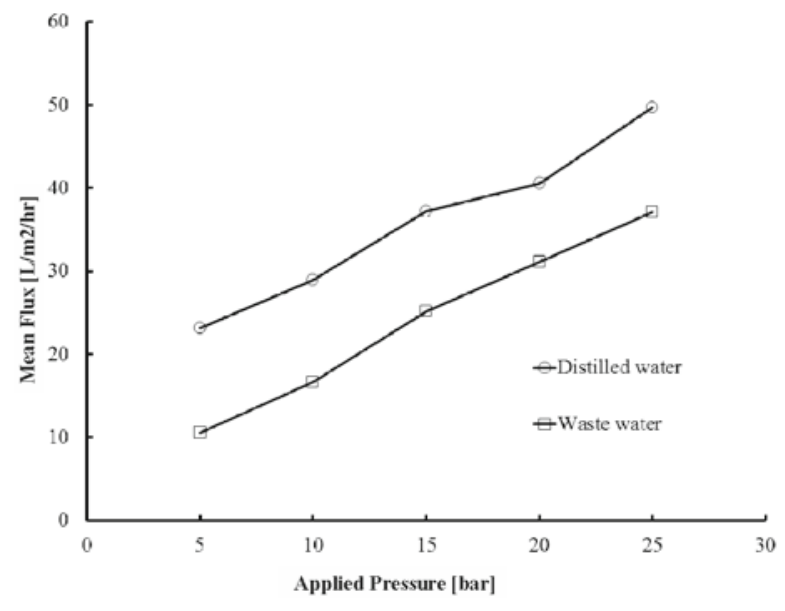

Figure 7. Effect of applied feed pressure on permeate flux

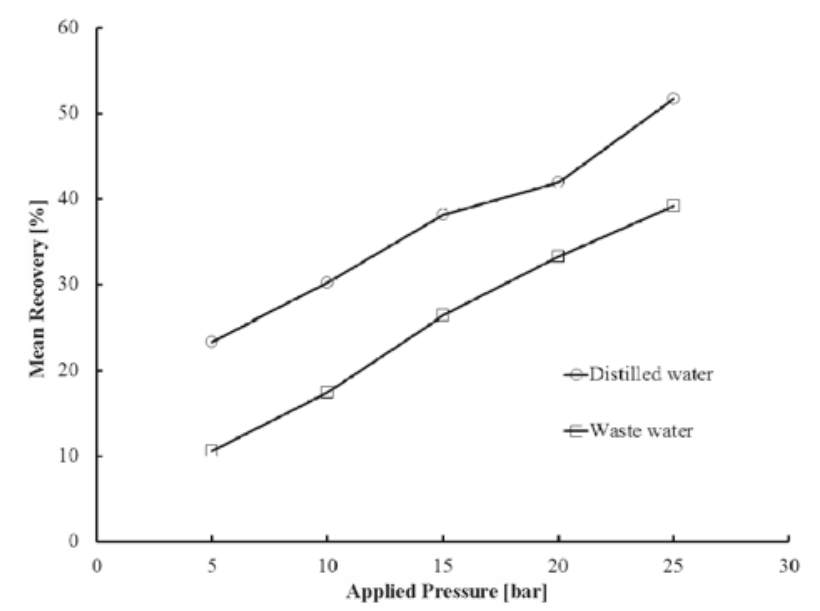

Figure 8. Effect of applied feed pressure on permeate recovery

and $88 \%$, respectively. Nevertheless, it should be noted that percent rejection of the pollutants as a function of applied pressure is strongly effected by strength of pollutants in raw water and temperature of the system. Goncharuk et al. in their experimental investigation showed the removal of Nitrates at low pressure operation of reverse osmosis ${ }^{29}$.

\section{Effect of applied feed pressure on rejection of different pollutants}

In Table 3 the raw (feed) and permeate water analysis with average values of $\pm 5 \%$ error are summarized. These results were obtained from a series of repeated experiments for wastewater treatment for which the plant was operated in a total recycled mode at feed pressures of 5-25 bar. The temperature varied between 24 and $26^{\circ} \mathrm{C}$. An increase in feed pressure resulted in a better rejection of pollutants but at the expense of specific power. Figure 9 shows the effect of applied pressure on percent rejection of different pollutants. There was maximum pollutant rejection at feed pressure of 25 bar above which there was no significant increase in rejection.

\section{CONCLUSION}

In the present study, RO process was evaluated for the treatment of polluted surface/ground water containing physical, chemical and microbiological contaminants. The RO plant was operated over a total time span of 100 
Table 3. Raw (feed) and permeate water analysis with average values of $\pm 5 \%$ error; Operating Pressure $20-30$ bar

\begin{tabular}{|c|c|c|}
\hline Parameter & Raw (feed) water & RO permeate \\
\hline $\mathrm{pH}$ & 7.4 & 6.4 \\
\hline Turbidity, NTU & 8.0 & 0.95 \\
\hline Total suspended solids (TSS), mg/L & 4.27 & - \\
\hline Total dissolved solids (TDS), mg/L & 504.7 & 21.6 \\
\hline Alkalinity $\left(\mathrm{HCO}_{3}^{-}\right)$ & 35.5 & 11.1 \\
\hline Chloride as $\mathrm{Cl}^{-1}$ & 700.0 & 53.7 \\
\hline Sulphate as $\mathrm{SO}_{4}^{-2}$ & 287.6 & 25.6 \\
\hline Sodium as $\mathrm{Na}^{+1}$ & 264.6 & 27.2 \\
\hline Nitrate as $\mathrm{NO}_{3}^{-1}$ & 50.0 & 5.74 \\
\hline Total Coliform /100 mL & 10 & $<1$ \\
\hline E. Coli $/ 100 \mathrm{~mL}$ & 60 & $<1$ \\
\hline
\end{tabular}

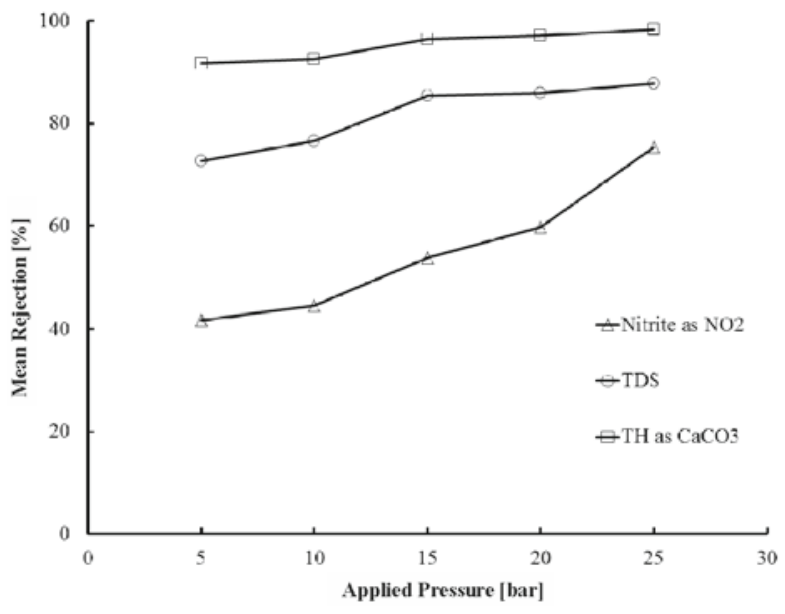

Figure 9. Effect of applied feed pressure on rejection of different pollutants

hours. After each experiment, thorough cleaning with $\mathrm{NaOH}$ and $\mathrm{HCl}$ solutions was performed to counter the buildup of organic and inorganic deposits on membrane surface. With microfiltration as a pre-treatment step, RO process rejected more than $94 \%$ of TDS at an operating pressure and temperature of 15 bar and $24-26^{\circ} \mathrm{C}$, respectively. A permeate flux of $20-30 \mathrm{~L} \cdot \mathrm{m}^{-2} \cdot \mathrm{h}^{-1}$ was achieved. It is thus concluded that RO process can offer an easy and efficient one-step wastewater treatment process for the removal of various contaminants. However, the process strongly depends on pollutants load and therefore may vary from point to point. For complete removal of microorganisms, an effective pre or post-treatment step must be coupled with RO. In the absence of such pre or post-treatment step, RO membranes can suffer higher fouling; higher membrane cleaning cost and lower permeate flux, thus resulting in reduced membrane life and higher clean water cost.

\section{NOMENCLATURE}

$\mathrm{Q}_{\mathrm{p}} \quad$ - Permeate Flow Rate

$\mathrm{Q}_{\mathrm{f}} \quad-$ Feed Flow Rate

$\mathrm{Q}_{\mathrm{R}} \quad$ - Retentate Flow Rate

$\mathrm{R}$ - Recovery ratio

X - Salt Concentration

\section{ACKNOWLEDGEMENT}

The study is mainly sponsored by the IEEE Foundation, Islamabad chapter (Pakistan) while authors also acknowledge the Pakistan Science Foundation (PSF), Islamabad, Pakistan for travel grant to present this study at the $1^{\text {st }}$ International Conference on Desalination using Membrane Technology held from 7-10 April 2013 in Sitges, Spain.

\section{LITERATURE CITED}

1. Derbalah, A., Ismail, A. \& Shaheen, S. (2013) Monitoring of organophosphorus pesticides and remediation technologies of the frequently detected compound (chlorpyrifos) in drinking water. Pol. J. Chem. Technol. 15(3) 25-34. DOI: $10.2478 /$ pjct-2013-0040.

2. Ullah, A., Khattak, M.N.K., Richter, P. \& Hader, D.P. (2011). Water pollution in Pakistan and its impact on public health- A review. Environ. Inter. J. 37(2), 479-497. DOI: 10.1016/j.envint.2010.10.007.

3. Saleem, M., Bukhari, A.A. \& Al-Malack, M.H. (2000). Removal efficiencies of indicator micro-organisms in the Al-Khobar waste treatment plant. Environ. Engine. Sci. 17(4), 227-232. DOI: 10.1089/10928750050137570.

4. Patil, I.D., Patil, Y.S. \& Pangarkar, B.L. (2013). Removal of lindane from wastewater using liquid-liquid extraction process. Pol. J. Chem. Technol.. 15(3) 81-84. DOI: 10.2478/ pjct-2013-0050.

5. George, I., Crop, P. \& Servais, P. (2002). Fecal coliform removal in wastewater treatment plants studied by plate counts and enzymatic methods. Water Res. 36(10), 26072617. DOI: 10.1016/S0043-1354(01)00475-4.

6. Koivunen, J., Siitonen, A. \& Heinonen-Tanski, H. (2003). Elimination of enteric bacteria in biological-chemical wastewater treatment and tertiary filtration units. Water Res. 37(3), 690-698. DOI: 10.1016/S0043-1354(02)00305-6.

7. Zhang, K. \& Farahbakhsh, K. (2007). Removal of native coliphages and coliform bacteria from municipal wastewater by various wastewater treatment processes: Implications to water reuse, Water Res. 41(12), 2816-2824. DOI: 10.1016/j. watres.2007.03.010.

8. Cheremisinoff, P.N. (2008). Handbook of water and wastewater technologies, Butterworth-Heinemann. DOI: 10.1016/ B978-075067498-0/50004-8.

9. Wintgens, T., Melin, T., Schafer, A., Khan, S., Muston, M., Bixio, D. \& Thoeye, C. (2005). The role of membrane processes in municipal wastewater reclamation and reuse. Desalination 178(1-3), 1-11. DOI: 10.1016/j.desal.2004.12.014. 
10. Der Bruggen, B.V. \& Vandecasteele, C. (2003). Removal of pollutants from surface water and groundwater by nanofiltration: overview of possible applications in the drinking water industry, Environ. Pollut. 122(3), 435-445. DOI: 10.1016/S0269-7491(02)00308-1.

11. Der Bruggen, B.V., Schaep J., Maes, W., Wilms, D. \& Vandecasteele, C. (1998). Nanofiltration as a treatment method for the removal of pesticides from ground waters. Desalination 117(1-3), 139-147. DOI: 10.1016/S0011-9164(98)00081-2.

12. Pendergast, M.T.M. \& Hoek, E.M.V. (2011). A review of water treatment membrane nanotechnologies. Energy Environ. Sci. 4(6), 1946-1971. DOI: 10.1039/C0EE00541J.

13. Escobar, I.C., Hong, S. \& Randall, A.A. (2000). Removal of assimilable organic carbon and biodegradable dissolved organic carbon by reverse osmosis and nanofiltration membranes. J. Memb. Sci. 175(1), 1-17. DOI: 10.1016/ S0376-7388(00)00398-7.

14. Pontie, M., Rapenne, S., Thekkedath, A., Duchesne, J., Jacquemet, V., Leparc, J. \& Suty, H. (2005). Tools for membrane autopsies and antifouling strategies in seawater feeds: a review. Desalination 181(1-3), 75-90. DOI: 10.1016/j.desal.2005.01.013.

15. Bai, L., Qu, F., Liqng, H., Ma, J., Chang, H., Wang, M. \& Li, G. (2013). Membrane fouling during ultrafiltration (UF) of surface water: Effects of sludge discharge interval (SDI). Desalination 319, 18-24. DOI: 10.1016/j.desal.2013.04.004.

16. Winfield, B.A. (1979). The treatment of sewage effluents by reverse osmosis- $\mathrm{pH}$ based studies of the fouling layer and its removal. Water Res. 13(7), 561-564. DOI: 10.1016/00431354(79)90001-0.

17. Winfield, B.A. (1979). A study of the factors affecting the rate of fouling of reverse osmosis membranes treating secondary sewage effluents. Water Res. 13(7), 565-569. DOI: 10.1016/0043-1354(79)90002-2.

18. Gryta, M., Bastrzyk, J. \& Lech, D. (2012). Evaluation of fouling potential of nanofiltration membranes based on the dynamic contact angle measurements. Pol. J. Chem. Technol. 14(3) 97-104. DOI: 10.2478/v10026-012-0091-4.

19. McCutcheon, J.R. \& Elimelech, M. (2006). Influence of concentrative and dilutive internal concentration polarization on flux behavior in forward osmosis. J. Memb. Sci. 284(1-2), 237-247. DOI: 10.1016/j.memsci.2006.07.049.

20. Cath, T.Y., Childress, A.E. \& Elimelech, M. (2006). Forward osmosis: principles, applications, and recent developments. J. Memb. Sci. 281(1-2), 70-87. DOI: 10.1016/j. memsci.2006.05.048.

21. Potts, D.E., Ahlert, R.C. \& Wang, S.S. (1981). A critical review of fouling of reverse osmosis membranes. Desalination 36(3), 235-264. DOI: 10.1016/S0011-9164(00)88642-7.

22. Hastuti, E. \& Wardiha, M.W. (2012). A study of brackish water membrane with ultrafiltration pretreatment in Indonesia's coastal area. J. Urban Environ. Engine. 6(1), 10-17. DOI: 10.4090/juee.2012.v6n1.010017.

23. Afonso, M.D., Jaber, J.O. \& Mohsen, M.S. (2004). Brackish groundwater treatment by reverse osmosis in Jordan. Desalination 164(2), 157-171. DOI: 10.1016/S00119164(04)00175-4.

24. Nataraj, S.K., Hosamani, K.M. \& Aminabhavi, T.M. (2006). Distillery wastewater treatment by the membrane-based nanofiltration and reverse osmosis processes. Water Res. 40(12), 2349-2356. DOI: 10.1016/j.watres.2006.04.022.

25. Yavuz, E., Arar, O., Yuksel, U., Yuksel, M. \& Kabay, N. (2013). Removal of boron from geothermal water by RO system-III-Utlization of SWRO system. Desalination 310(1), 140-144. DOI: 10.1016/j.desal.2012.07.046.

26. Jawad, M.A., Al-Shammari, S. \& Al-Sulaimi, J. (2002). Non-Conventional treatment of treated municipal wastewater for reverse osmosis. Desalination 142(1), 11-18. DOI: 10.1016/S0011-9164(01)00421-0.
27. Mierzwa, J.C., Da Silva, M.C.C., Veras, L.R.V., Subtil, E.L., Rodrigues, R., Li, T. \& Landenberger, K.R. (2012). Enhancing spiral-wound ultrafiltration performance for direct drinking water treatment through operational procedures improvement: A feasible option for the Sao Paulo Metropolitan region. Desalination 307, 68-75. DOI: 10.1016/j.desal.2012.09.006.

28. Turan, M. (2004). Influence of filtration conditions on the performance of nanofiltration and reverse osmosis membranes in dairy wastewater treatment. Desalination 170(1), 83-90. DOI: 10.1016/j.desal.2004.02.094.

29. Goncharuk, V.V., Osipenko, V.O., Balakina, M.N. \& Kucheruk, D.D. (2013). Water purification of nitrates by low pressure reverse osmosis method. J. Water Chem. Technol. 35(2), 71-75. DOI: 10.3103/S1063455X13020045. 